\title{
ASSESSMENT OF LEAD CONTAMINATION IN DIFFERENT SAMPLES AROUND THE INDUSTRIAL VICINITY IN SELECTED AREAS OF BANGLADESH
}

\author{
M. A. Hossain ${ }^{1}$, M. Mostofa ${ }^{2 *}$, M. N. Alam ${ }^{2}$, M. R. Sultana ${ }^{3}$ and M. M. Rahman ${ }^{2}$ \\ ${ }^{1}$ Department of Pharmacology and Toxicology, Sylhet Agricultural University, Sylhet-3100, Bangladesh, \\ ${ }^{2}$ Department of Pharmacology, Bangladesh Agricultural University, Mymenshingh, Bangladesh, ${ }^{3}$ Department of \\ Animal Husbandry and Veterinary Science, University of Rajshahi, Bangladesh
}

\begin{abstract}
Lead has long been recognized as a poison to living organisms, with negative effects on general health, reproduction, behavior and mental growth. Drinking water, surface water, industrial waste water, agricultural soil and egg samples were collected to determine the presence of lead. Twenty samples (3-5 g) from each category were collected and detected by Flame Atomic Absorption Spectrophotometer (FAAS) to detect the natural deposition of lead. The analysis of variance of mean lead concentration among different samples in different locations differed significantly $(\mathrm{P}<0.01)$. The highest mean values of lead accumulation in drinking water, industrial waste water and agricultural soil samples, collected from Norshindi district was detected as $0.064 \pm 0.021 \mathrm{ml} / \mathrm{kg}, 95.735 \pm 9.593 \mathrm{ml} / \mathrm{kg}$ and $119.033 \pm 9.853 \mathrm{mg} / \mathrm{kg}$ respectively. The highest mean value of lead $(0.622 \pm 0.096 \mathrm{mg} / \mathrm{L})$ in surface water was significantly $(\mathrm{P}<0.01)$ present in Narayangonj district and significantly $(\mathrm{P}<0.01)$ higher than other selected areas. Analysis of variance of data on chicken eggs revealed significant $(\mathrm{P}<0.001)$ difference in egg albumen, egg yolk and egg shell. The highest mean values of lead were $0.066 \pm 0.003 \mathrm{mg} / \mathrm{kg}, 0.089 \pm 0.010 \mathrm{mg} / \mathrm{kg}$ and $0.251 \pm 0.032 \mathrm{mg} / \mathrm{kg}$ in egg albumen, egg yolk and egg shell in Norshindi. The natural accumulation of lead in Drinking water, egg albumen and egg yolk was found at tolerance level but the cumulative accumulation may bring the serious public health hazards.
\end{abstract}

Keywords: Environment, Lead, Water, Effluents, Soil, Chickens

\section{INTRODUCTION}

Lead constitutes a potential danger to humanity with increased rate of industrialization (Khan et al., 1996). Lead is an element of risk for the environment and human health and has harmful effects that may exceed those of other inorganic toxicants. Industries are the major sources of lead pollution that contribute toxic metal lead to the environment (Hernandez et al., 1987). Lead $(\mathrm{Pb})$ interferes the hemato-biochemical pathways with cumulative accumulation of lead to the body tissues (Mazliah et al., 1989). The whole food chain becomes contaminated due to the extensive contamination of all parts of environment. This pollution gives rise to the progressive accumulation of lead compounds in the aquatic environment (Hernandez et al., 1987). Contamination is transferred to food animals via direct exposure of lead, lead polluted water; crops grown on lead contaminated irrigated water and industrial effluents. Another important reason for causing lead contamination of food animals is the deposition of contaminants to the soil or aquatic environment from vehicular emission. Among various pollutants in the environment, lead is directly related to public health issues (Rabinowitz, 1991). Pollution of the environment with toxic metals and radioactive waste has dramatically increased since the beginning of the industrial revolution (Emongor et al., 2005). There are many ways in which people are exposed to lead. Although adverse health effects of lead have been known for a long time, exposure to lead continues and is even increasing in some areas of the country. The main sources of lead pollution in the environment are: Industrial production processes and their emissions, road traffic with leaded petrol, the smoke and dust emissions of coal and gas-fired power stations, the laying of lead sheets by roofers as well as the use of paints and anti-rust agents (Logan et al., 1983. Lead intoxication in livestock has historically been associated with cattle turned out to pasture and accidental ingestion of lead contaminated leaching materials (Roegner et al., 2013).

Lead contamination of crop and vegetables in urban soils occurred through plant uptake of lead when grown in lead contaminated environment. Lead may mobilize from soil when lead-bearing soil particles run off to surface waters due to heavy rains.

*Corresponding e-mail address: mostof57@yahoo.com

Copyright (c) 2014 Bangladesh Society for Veterinary Medicine

All rights reserved 0293/2014 


\section{A. Hossain and others}

Lead contaminated plants and soil are major source of contamination of livestock. The application of fertilizers increases the lead bioavailability in soils due to the chemical alterations they provoked in the system (Tu et al., 2002). There are many ways in which people are exposed to lead. Lead is known to be a toxic agent, and blood lead level (BLL) is a convenient and direct indicator of such toxicity. Lead poisoning may affect numerous organ systems and is associated with a number of morphological, biochemical and physiological changes, including kidney dysfunction, abnormal glucose metabolism, nervous system disturbances, impairment of liver function and hematological disorders (Ghorbe et al., 2001). Exposure to lead significantly decreased red blood cell counts, hemoglobin levels and hematocrit values (Terayama, 1993). Anemia accompanying lead poisoning has the inhibitory effects of lead on heme biosynthesis. Exposure to lead in drinking water significantly decreased red blood cell count, hemoglobin concentration and hematocrit value (Bersenyi et al., 2003). As environmental pollution is one of our urgent practical attentions, therefore, it was needed to determine the deposition of lead in different samples in selected areas of Bangladesh.

\section{MATERIALS AND METHODS}

In this study FAAS (Flame Atomic Absorption Spectrophotometer) was used to analyze the collected samples as described in the manufacturer's instruction manual. Certified stock sample, Hollow Cathode Lamp (HCL), Air-acetylene gas and specific specification were applied in the analysis of prepared samples by FAAS, model AA-990, UK with Zeeman background correction by subtracting the background absorption from the total absorption. The instrument was installed in the Department of Pharmacology, Bangladesh Agricultural University funded by USDA Project.

\section{Selection of Sites}

Six different districts of Bangladesh i.e., Dhaka, Narayangonj, Norshindhi, Gazipur, Chittagong and Sylhet were selected as sites for collection of samples.

\section{Types and Number of Samples}

The environmental samples were collected according to the standard procedures and they were analyzed properly for the presence of total lead. The considered environmental samples were drinking water (ground water), surface water, industrial waste water, agricultural soil and egg samples. Twenty (20) samples from each category from six different districts of Bangladesh were collected from the vicinity of industrial set up in order to detect the environmental deposition of lead in the said samples. The samples were analyzed for lead concentration and expressed as mili gram per $\mathrm{kg}$ (ppm, parts per million).

\section{Sample Collection Procedures \\ Drinking Water (Ground Water)}

Drinking water samples from running tap water were collected in sterile screw cap acid-washed $100 \mathrm{ml}$ plastic vials according to standard methods as described in APHA (1998). Prior to the collection of samples, $5 \mathrm{ml}$ of $2 \%$ $\mathrm{HCl}$ were poured into the vials and were filled with $95 \mathrm{ml}$ collected water samples.

\section{Surface Water and Industrial Waste Water}

The surface water and industrial waste water samples collection procedures are quite different from drinking water. More careful attention was paid during the collection of surface water and industrial waste water samples. The collecting container was attached to a water scoop then filled by plunging under the water surface and sweeping forward, using great care not to disturb the bed of such source. The samples were collected in sterile screw cap acid-washed $100 \mathrm{ml}$ plastic vials. Before sampling, the bottles were accordingly washed with tap water followed by acid washed and finally several times with doubled distilled deionized water. The samples were sent to laboratory as soon as possible. The samples from the collecting container were poured through the Whatman 42 filter paper to prevent coarse material from passing through (Tessier et al., 1999). All glassware was carefully cleaned with a solution of $1 \%$ nitric acid for $48 \mathrm{~h}$ followed by rinsing with deionized water. 


\section{Agricultural Soil}

The soil samples used in these experiments were collected from the agricultural fields. Atmospheric lead is retained in the soil samples from $2-5 \mathrm{~cm}$ in undisturbed soil and up to $15 \mathrm{~cm}$ in disturbed soil (EPA, 1986). Using a serving spoon, the soil samples were collected from the top to $5 \mathrm{~cm}$ in case of undisturbed soil and up to $15 \mathrm{~cm}$ in case of disturbed soil at several locations and preserved in plastic bottles for chemical analysis. The surface of the soil was shaved a 1-inch-thick slice of soil. 100-200g soil samples were collected in zip lock plastic bag by using the stainless steel spoon and shovel. The collected soil samples were dumped into a plastic bucket; mix the soil samples using a nonmetal tool until they are uniformly combined. The mixture of soil sample was thoroughly shaken together in plastic bags to allow for homogeneity. Soil samples were air dried and grind with a mortar and pestle. The samples were placed properly and protected in zip lock poly bags. The samples were allowed to air dry and mixed well. The air-dried samples were put in a clean plastic bag and sealed. The plastic bags were labeled and recorded by the permanent marker pen. The samples were passed through the sieve for the chemical treatment. Soil samples were ground to pass through a 2-mm nylon screen and screened with a No. 14 sieve to obtain a uniform sample. 2-3 gram of soil samples were digested with ultrapure grade concentrated Nitric acid $(5.0 \mathrm{ml})$ and Perchloric acid $(2.5 \mathrm{ml})$, and left overnight in sample digestion block. The predigested soil samples were heated step by step up to a final temperature at $120^{\circ} \mathrm{C}$ for complete digestion according to the methods as described by Alonso et al. (2000) for lead analysis.

\section{Egg Samples}

Eggs were waterlogged for $4 \mathrm{hrs}$. The eggs were brushed and cleaned to eliminate external contamination. Eggs were thoroughly rinsed in deionized water and allowed to air-dry. Eggs were separated into albumen, yolk and shell and thoroughly blended before weighing for analysis. Shells were rinsed and dried in a drying oven, and the concentrations of lead were determined on wet weights basis. Shells were blended to a diameter of $1 \mathrm{~mm}$ or less before weighing for analysis to obtain a uniform sample. 2-3 g poultry egg samples were digested with ultrapure grade concentration Nitric Acid $(5.0 \mathrm{ml})$, Perchloric Acid $(2.5 \mathrm{ml})$ and 30\% Hydrogen Peroxide $(2.5 \mathrm{ml})$ and left overnight in sample digestion chamber. $5 \mathrm{ml}$ concentrated ultrapure Nitric acid, $2.5 \mathrm{ml}$ of $30 \%$ Hydrochloric Acid and $2.5 \mathrm{ml}$ Per Chloric acids was added to 2 gram samples and were heated step by step up to a final temperature at $120^{\circ} \mathrm{C}$ for complete digestion according to the methods as described by Alonso et al. (2000).

\section{Sample Digestion Procedure}

Digestion of samples was done using a mixture of ultrapure grade concentrated $5.0 \mathrm{ml}$ Nitric Acid $\left(\mathrm{HNO}_{3}\right), 2.5$ $\mathrm{ml}$ Hydrogen Peroxide $\left(\mathrm{H}_{2} \mathrm{O}_{2}\right)$ and $2.5 \mathrm{ml}$ Perchloric Acid $\left(\mathrm{HClO}_{4}\right)$ and left overnight in sample digestion block. The predigested samples were heated at $120^{\circ} \mathrm{C}$ for complete digestion. The digested samples were then filtered and stored in a nitric acid prewashed polyethylene bottle for analysis. The colors of the completely digested samples were fined crystal clear that prosecuted the complete digestion of samples. Samples were then filtered through Whatman (Maidstone, UK) filter paper to prevent coarse material from passing through. All glass wares were carefully cleaned with a solution of $1 \%$ nitric acid for $48 \mathrm{~h}$ followed by rinsing with deionized water. In order to determine the reliability of instruments, a blank and known standard were run after every 6 samples. The samples were analyzed for lead by flame atomic absorption spectrophotometer (AAS) as described by Jacobson et al. (1991).

\section{Statistical Analysis}

The statistical analysis of variance was analyzed by Duncan's Multiple Range Test (DMRT) using the General Linear Models (GLM) procedure of SAS software (SAS, 1985). Duncan's multiple range tests were also used to locate the calculated means that are significantly different. Results were displayed as means \pm standard error (SE).

\section{RESULTS AND DISCUSSION}

Drinking water (ground water), surface water (water from canals, lakes, ponds etc.), industrial waste water (effluents), agricultural soil (crop land) and egg samples from different locations of six districts of the country was tested for lead determination. The results obtained are summarized in the Table 1 and Fig. 1 and Fig. 2. 


\section{A. Hossain and others}

The highest levels of environmental lead in drinking water were detected from the Norshindi district that was identified as $0.064 \pm 0.021 \mathrm{ml} / \mathrm{L}$. The ranges of lead concentration in the drinking water were $0.029-0.071 \mathrm{mg} / \mathrm{L}$, $0.021-0.253 \mathrm{mg} / \mathrm{L}, 0.023-0.452 \mathrm{mg} / \mathrm{L}, 0.023-0.091 \mathrm{mg} / \mathrm{L}, 0.024-0.095 \mathrm{mg} / \mathrm{L}$, and $0.022-0.081 \mathrm{mg} / \mathrm{L}$, in Dhaka, Narayangonj, Norshindi, Gazipur, Chittagong and Sylhet, respectively. The mean values of lead contaminated drinking water were significantly different $(\mathrm{P}<0.01)$ in comparison with other types of environmental samples collected from different six districts of the country.

The present study also demonstrated the varying degrees of lead levels in surface water. The ranges of lead concentration in the surface water collected from the different locations of selected six districts were 0.035 $1.114 \mathrm{mg} / \mathrm{L}, 0.026-1.063 \mathrm{mg} / \mathrm{L}, 0.044-1.075 \mathrm{mg} / \mathrm{L}, 0.045-1.085 \mathrm{mg} / \mathrm{L}, 0.094-1.285 \mathrm{mg} / \mathrm{L}$, and $0.035-$ $1.657 \mathrm{mg} / \mathrm{L}$, in Dhaka, Narayangonj, Norshindi, Gazipur, Chittagong and Sylhet, respectively. The highest mean value of lead $(0.622 \pm 0.096 \mathrm{ml} / \mathrm{L})$ in surface water was detected in Narayangonj and was significantly $(\mathrm{P}<0.01)$ higher among the different locations of different selected six districts. The surface water collected from different locations of six districts was found unprotected, untreated and not under the control of regulatory bodies of Bangladesh.

The industrial waste water was collected as a composite sample with the aim to determine the concentration of lead. Industries are mainly concentrated in major urban areas like Dhaka the capital, the inland port city Narayanganj, highly concentrated industrial and economic growth centre Norshindi and Gazipur, seaport city Chittagong, and in Sylhet. Industrial waste water from different selected districts of the country was tested for lead determination and summarized in Table 1 . The highest mean value of lead $(95.735 \pm 9.593 \mathrm{ml} / \mathrm{L})$ in industrial waste water was detected in Norshindi. The ranges of lead concentration in the industrial waste water collected from the different districts were 14.551-165.463 ml/L, 27.322-216.241 ml/L, 26.711-192.343 ml/L, 5.162 $88.434 \mathrm{ml} / \mathrm{L}, 19.842-175.245 \mathrm{ml} / \mathrm{L}$, and $6.192-38.414 \mathrm{ml} / \mathrm{L}$, in Dhaka, Narayangonj, Norshindi, Gazipur, Chittagong and Sylhet, respectively. The mean values of environmental lead concentration in industrial waste water samples were significantly different $(\mathrm{P}<0.01)$ in comparison to the other types of samples collected from different districts.

Table 1. Environmental concentration of lead $(\mathrm{Pb}, \mathrm{ppm})$ in different environmental samples in different districts

\begin{tabular}{|c|c|c|c|c|c|c|c|}
\hline \multirow{2}{*}{$\begin{array}{l}\text { Name of } \\
\text { Samples }\end{array}$} & \multicolumn{6}{|c|}{ Name of Locations } & \multirow{2}{*}{$\begin{array}{c}\text { P- } \\
\text { Values }\end{array}$} \\
\hline & Dhaka & Narayangonj & Norshindi & Gazipur & Chittagong & Sylhet & \\
\hline $\begin{array}{l}\text { Drinking } \\
\text { Water (ml/L) }\end{array}$ & $0.052 \pm 0.002 \mathrm{a}$ & $0.058 \pm 0.012 \mathrm{a}$ & $0.064 \pm 0.021 \mathrm{a}$ & $\begin{array}{l}0.048 \pm 0.00 \\
5 \mathrm{a}\end{array}$ & $\begin{array}{l}0.037 \pm 0.005 \\
\mathrm{a}\end{array}$ & $\begin{array}{l}0.031 \pm 0.004 \\
\mathrm{a}\end{array}$ & $\begin{array}{l}0.0672 \mathrm{~N} \\
\mathrm{~S}\end{array}$ \\
\hline $\begin{array}{l}\text { Surface } \\
\text { Water }(\mathrm{ml} / \mathrm{L})\end{array}$ & $0.412 \pm 0.087 \mathrm{~b}$ & $0.622 \pm 0.096 \mathrm{~b}$ & $0.507 \pm 0.102 b$ & $\begin{array}{l}0.428 \pm 0.09 \\
8 b\end{array}$ & $\begin{array}{l}0.468 \pm 0.078 \\
\text { b }\end{array}$ & $\begin{array}{l}0.319 \pm 0.120 \\
\text { b }\end{array}$ & $\begin{array}{l}0.0892 \mathrm{~N} \\
\mathrm{~S}\end{array}$ \\
\hline $\begin{array}{l}\text { Industrial } \\
\text { Waste Water } \\
(\mathrm{ml} / \mathrm{L})\end{array}$ & $77.215 \pm 10.005 c$ & $84.488 \pm 11.540 \mathrm{c}$ & $95.735 \pm 9.593 c$ & $\begin{array}{l}38.859 \pm 5.7 \\
66 \mathrm{c}\end{array}$ & $\begin{array}{l}74.751 \pm 10.0 \\
55 \mathrm{c}\end{array}$ & $\begin{array}{l}20.496 \pm 2.30 \\
8 \mathrm{c}\end{array}$ & $\begin{array}{l}0.0674 \mathrm{~N} \\
\mathrm{~S}\end{array}$ \\
\hline $\begin{array}{l}\text { Agricultural } \\
\text { Soil (mg/kg) }\end{array}$ & $97.513 \pm 16.188 \mathrm{~d}$ & $\begin{array}{l}105.943 \pm 18.984 \\
\mathrm{~d}\end{array}$ & $\begin{array}{l}119.033 \pm 9.853 \\
\mathrm{~d}\end{array}$ & $\begin{array}{l}79.059 \pm 16 . \\
261 \mathrm{~d}\end{array}$ & $\begin{array}{l}106.237 \pm 14 . \\
244 d\end{array}$ & $\begin{array}{l}86.729 \pm 10.0 \\
71 \mathrm{~d}\end{array}$ & $\begin{array}{l}0.0952 \mathrm{~N} \\
\mathrm{~S}\end{array}$ \\
\hline
\end{tabular}

Means belonging the same superscripts did not differ significantly. Each value is the mean of 20 samples. Values in the figures indicate mean \pm Standard error (SE). Data were calculated at $99 \%$ level of significance.

The agricultural soil samples that were analyzed were found a wide range of environmental lead. A rich level of lead was detected in the collected soil samples in comparison to the other types of environmental samples. The ranges of lead concentration in the agricultural soil collected from the different regions were 28.613-325.311 $\mathrm{mg} / \mathrm{Kg}, 29.273-412.951 \mathrm{mg} / \mathrm{Kg}, 35.292-224.173 \mathrm{mg} / \mathrm{Kg}, 25.911-261.253 \mathrm{mg} / \mathrm{Kg}, 36.491-259.212 \mathrm{mg} / \mathrm{Kg}$, and 24.044-223.163 mg/Kg, in Dhaka, Narayangonj, Norshindi, Gazipur, Chittagong and Sylhet, respectively. The mean values of environmental lead in agricultural soil among different areas were 
significantly different $(\mathrm{P}<0.01)$. The highest mean value of lead $(119.033 \pm 9.853 \mathrm{mg} / \mathrm{Kg})$ in agricultural soil was detected in Norshindi and was significantly $(\mathrm{P}<0.01)$ higher among the different locations of different selected six districts.

The aim of this study was also to detect the environmental or natural accumulation of lead in chicken eggs. The results of lead concentration in chicken eggs were also furnished in mean \pm standard error (SE). Analysis of variance of data on chicken eggs revealed significant difference between egg albumen, egg yolk and egg shell. The results of the concentration of lead in chicken eggs are summarized in tables (Table 2) and figures (Fig. 1 and Fig. 2). The highest levels of environmental lead in egg samples were detected from the Norshindi district that were identified as $0.251 \pm 0.032 \mathrm{mg} / \mathrm{kg}, 0.89 \pm 0.010$ and $0.066 \pm 0.003$ in egg shell, egg yolk and egg albumen, respectively. The mean values of environmental lead in egg shell differed significantly $(\mathrm{P}<0.01)$ compared to egg yolk and egg albumen. Varying levels of lead were deposited in eggs especially in egg shells.

Table 2. Environmental concentration of lead ( $\mathrm{ppm})$ in egg samples in different districts

\begin{tabular}{|c|c|c|c|c|c|c|c|}
\hline \multirow{2}{*}{$\begin{array}{l}\text { Name of } \\
\text { samples }\end{array}$} & \multicolumn{6}{|c|}{$($ Mean \pm SE) } & \multirow{2}{*}{$\begin{array}{c}\text { P- } \\
\text { Values }\end{array}$} \\
\hline & Dhaka & Narayangonj & Norshindi & Gazipur & Chittagong & Sylhet & \\
\hline $\begin{array}{l}\text { Egg } \\
\text { Albumen }\end{array}$ & $\underset{\mathrm{a}}{0.022 \pm 0.002}$ & $0.025 \pm 0.002^{\mathrm{a}}$ & $0.066 \pm 0.003^{\mathrm{a}}$ & $0.024 \pm 0.005^{\mathrm{a}}$ & $0.023 \pm 0.006^{\mathrm{a}}$ & $0.022 \pm 0.023^{\mathrm{a}}$ & $0.063^{\mathrm{NS}}$ \\
\hline Egg Yolk & $\underset{\mathrm{a}}{0.034 \pm 0.008}$ & $0.047 \pm 0.006^{\mathrm{a}}$ & $0.089 \pm 0.010^{\mathrm{a}}$ & $0.043 \pm 005^{\mathrm{a}}$ & $0.033 \pm 0.011^{\mathrm{a}}$ & $0.024 \pm 0.005^{\mathrm{a}}$ & $0.072^{\mathrm{NS}}$ \\
\hline Egg Shell & $0.133 \pm 0.046$ & $0.203 \pm 0.028^{b}$ & $0.251 \pm 0.032^{b}$ & $0.222 \pm \frac{20.060}{b}$ & $0.129 \pm 0.034^{\mathrm{a}}$ & $0.122 \pm 0.056^{\mathrm{c}}$ & $0.0613^{\mathrm{NS}}$ \\
\hline
\end{tabular}

Means belonging the same superscripts did not differ significantly. Each value is the mean of 20 samples. Values in the figures indicate mean \pm Standard error $(\mathrm{SE})$. Data were calculated at $99 \%$ level of significance.

The present results showed that the concentration of lead in water was higher than the maximum toxic level (0.05 mg/L) recommended by WHO (1995). Ground Water contamination with lead has been reported in many countries (Kido et al., 1989). Lead emitted by industries, traffic, municipal wastes, and hazardous wastes sites (HWS) results in a steady rise in contamination of ground water (Yang et al., 2001). According to Bangladesh Standards for Testing Institution (8) the maximum permissible limit for arsenic (As) is $0.05 \mathrm{mg}$ per litre, but BSTI has not yet been standardized the maximum permissible limit for lead. Contaminated surface water is the potential source of contamination of aquatic food animals. Surface water pollution is one of the most serious problems, which requires our urgent practical attention. These pollutants emerge from rapid population growth, massive urbanization and extensive industrialization (Raja et al., 1996). It can be evident from the present study that the problem is serious because the whole chain of food production for consumption neither controlled nor regulated. The risk of lead contamination in surface water is much higher than the groundwater and industrial waste water was badly affected and completely unsuitable for any intended use.

Bangladesh Industrial Effluent Standards, for cromium is $0.1 \mathrm{mg} / \mathrm{L}$ (Alam and Hossain, 2009). There is no such report available for Bangladesh Industrial Effluent Standards (BIES) for lead. Therefore, it was needed to conduct a baseline study to estimate the concentration of lead in industrial waste water samples collected from different locations of selected six districts. The super-abundance level of lead causes a disruption in the ecological balance. A study by Ayodele et al. (1991) reported that industries contribute large quantities of lead through the discharge of effluents. Dhaka, Narayangonj, Norshindi, Gazipur, Chittagong are the major industrial centre of the country, is faced with serious problems of industrial waste disposal. However, in the vicinity of industrial sites some hot spots of soil were detected arsenic concentrations as high as $5020 \mathrm{mg} / \mathrm{kg}$ (Chowdhury et $a l ., 2009)$. But there is no such report for toxic heavy metal lead from industrial facilities in Bangladesh. Present study revealed a scenario of the concentration of lead from untreated industrial waste water. 


\section{A. Hossain and others}

The total mean lead concentration in the agricultural soil of Dhaka, Gazipur, Chittagong and Sylhet is within the range of critical reported values (100 to $400 \mathrm{mg} / \mathrm{kg}$ ) mentioned by Kabata et al. (2000). Soil lead levels were found a quite large variation with the location. It may range up to $30 \mathrm{mg} / \mathrm{kg}$ in rural areas, $3 \mathrm{~g} / \mathrm{kg}$ in urban areas, and 20g/kg near point sources (EPA, 1986; ATSDR, 1993). High levels of heavy metals can damage soil fertility and may affect productivity (CDC, 2009; Logan et al., 1983). Lead inhibits the uptake of essential nutrients by plant tissues from the soil (Emongor et al., 2005). Commercial fertilizers are being used in agricultural soil for many decades and have been playing a critical role in increasing food production around the world. However, some phosphatic and micronutrient fertilizers may contain elevated quantities of heavy metals such as cadmium (Cd), lead (Pb), Cobalt (Co) Nickel (Ni) and fluorine (Raven et al., 1997). Background concentrations of lead $(\mathrm{Pb})$ that occur naturally in surface agricultural soils in the United States is 10 parts per million (ppm) with a range of 7 to $20 \mathrm{ppm}$ (Holmgren et al., 1993). Soils with lead levels above this range are primarily the result of lead contamination. Lead does not biodegrade, or disappears over time, but may remain in soils for thousands of years without change (ATSRD, 1993).

There was no relationship between the concentration of lead in the egg yolk and egg albumen with egg shells. These concentrations are lower than those reported in a previous study (Mazliah et al., 1989). Lead residues in egg yolk and eggshell from $\mathrm{Pb}$-dosed chickens were significantly higher than in control. $\mathrm{Pb}$ in albumen was generally low and was not influenced by $\mathrm{Pb}$ treatment which is also consistent to the several other studies (Mazliah et al., 1989). It may be concluded from the present study that eggs accumulated environmental or natural lead in their shells, yolk, and albumen with the highest concentration occurring in the shells as was also reported earlier by Vengris and Mare (1974). The concentration of lead analysis of the eggs in this study showed that lead in edible portion of eggs was found to be of accepted level which is at present not in alarming stage but repeated consumption of lead exposed chickens may bring a serious public health hazard. Repeated consumption of lead contaminated eggs might provide a continuing dietary source of lead resulting potential public health hazard. Significantly $(\mathrm{P}<0.01)$ increased levels of $\mathrm{Pb}$ was detected in eggshell, in comparison with the egg yolk and egg albumen although the difference between the egg yolk and egg albumen did not differ significantly $(P>$ 0.05). These results are in agreement with several other researchers (Mazliah et al., 1989). Mazliah et al. (1989) also demonstrated that egg albumen contained a lower amount of lead than egg yolk or eggshell.

\section{ACKNOWLEDGEMENT}

The author is thankful to Bangladesh Agricultural Research Council (BARC), Farmgate, Dhaka, Bangladesh, University Grants Commission (UGC), Bangladesh and USDA project, Bangladesh for providing the fund to carry out the present research work as a part of PhD Program.

\section{REFERENCES}

1. Alam R and Hossain MD (2009). Wastewater quality of natural gas fertilizer factory, Fenchuganj and water quality of Kushiara River at the down stream. Environmental Monitoring and Assessment 154(1-4): 127-133.

2. Alonso ML, Benedito JL, Miranda M, Castillo C, Hernandez J and Shore RF (2000). Arsenic, cadmium, lead, copper and zinc in cattle from Galicia, NW Spain. Science of the Total Environment 246: 237-248.

3. APHA (American Public Health Association) (1998). Standard Method for the Examination of Water and Wastewater. $20^{\text {th }}$ edition, America, Water Works Association and Water Pollution Control Federation, Washington DC.

4. ATSDR (Agency for Toxic Substances and Disease Registry) (1993). Toxicological profile for lead, Update. Prepared by Clement International Corporation under contact no. 205-88-060 for ATSDR, U.S. Public Health Services, Atlanta, GA.

5. Ayodele JT, Momoh RU and Amin M (1991). Determination of heavy metals in Sharada Industrial effluents in Water Quality Monitoring and Environmental Status in Nigeria. Proceedings of the National Seminar on Water Quality Monitoring and Status in Nigeria, Organized by Federal Environmental Protection Agency and National Water Resources Institute, Published by Federal Environmental Protection Agency, October 16-18: 158-166.

6. BBS (2005). Compendium of Environment Statistics of Bangladesh. Bangladesh Bureau of Statistics, Planning Division, Ministry of Planning, Government of Bangladesh.

7. Bersenyi A, Fekete $\mathrm{S}$ and Szoes Z (2003). Effect of ingested heavy metals $(\mathrm{Cd}, \mathrm{Pb}$ and $\mathrm{Hg}$ ) on haematology and serum biochemistry in rabbits. Acta Veterinaria Hungarica 51: 297- 304. 
8. BSTI (1989). Bangladesh Standard Specification for Drinking Water. 116/A, Tejgaon industrial area, Dhaka - 1208, Bangladesh Standards for Testing Institution, Bangladesh.

9. CDC (Centers for Disease Control) (2009). Preventing Lead Poisoning in Young Children. Atlanta, GA: Centers for Disease Control.

10. Chowdhury UK, Biswas BK, Dhar RK, Samanta G, Mandal BK, Roy D, Chakraborti S and Roy S (2009). Groundwater arsenic contamination and suffering of people in Bangladesh. In Arsenic exposure and health effects. WR Chappell, CO Abemathy and RL Calderon. Elsevier Science BV, UK, p.165-182.

11. Emongor V, Ramolemana EM, Machacha S, Khonga EB and Marumo K (2005). The heavy metal content of Gaborone secondary sewage effluent in Botswana. Botswana Journal of Agriculture and Applied Science 1: 57-62.

12. EPA (Environmental Protection Agency) (1986). Air quality criteria for lead 1986 and Addendum, September 1986. Research Triangle Park, NC.

13. Ghorbe F, Boujelbene M and Makni-Ayadi F (2001). Effect of chronic lead exposure on kidney function in male and female rats, determination of lead exposure biomarker. Archives of Physiology and Biochemistry 109: 457-463.

14. Hernandez L, Rico MMC, MJ Gonzalez and Hernan MA (1987). Environmental contamination by lead and cadmium in plants from urban area of Madrid, Spain. Bulletin of Environmental Contamination and Toxicology 38: 203-208.

15. Holmgren GG, Meyer MW, Chaney RL and Daniels RB (1993). Cadmium, lead, copper, and nickel in agricultural soils of the United States of America. Journal of Environmental Quality 22: 335-348.

16. Jacobson BE, Lokltch O and Qulgley GC (1991). Improve sample preparation for accurate determination of low concentration of lead in whole blood by graphite furnace analysis. Analytical Chemistry 37: 515-519.

17. Kabata-Pendias A and Pendias H (2000). Trace elements in soils and plants. CRC Press, Boca Raton, FL, 2000.

18. Khan KH, Ahmad N, Sial JK and Khan MI (1996). Ground water pollution by heavy metals. Journal of Science, Technology and Development 14: 1-5.

19. Kido K, Shiratori T, Watanabe T, Nakatsuka H, Ohashi M and Ikeda M (1989). Correlation of tetrachloroethylene in blood and in drinking water: a case of well water pollution. Bulletin of Environmental Contamination and Toxicology 43:444-453.

20. Logan TJ and Chaney RL (1983). In: Proceedings of the workshop on utilization of municipal wastewater and sludge on land. University of California, Riverside p. 235-326.

21. Mazliah J, Barron S, Bental E and Reznik I (1989). The effect of chronic lead intoxication in mature chickens. Avian Diseases 33: 566-570.

22. Raja IA, Ahmad MA and Nawaz M (1996). Disposal of condensed matter pollutants and associated problems in Pakistan. Journal of Science, Technology and Development 15: 41-50.

23. Raven KP and Leoppert RH (1997). Trace element composition of fertilizers and soil amendments. Journal of Environmental Quality 26: 551-557.

24. Rabinowitz MB (1991). Toxicokinetics of bone lead. Environmental Health Perspectives 91: 33-37.

25. Roegner A, Federico Giannitti, Woods L, Mete A, Puschner B (2013). Public health implications of lead poisoning in backyard chickens and cattle. Veterinary Medicine: Research and Reports 4: 11-20.

26. SAS Institute (1985). SAS User's Guide: Statistics. Version 5 Edition, SAS Institute Inc, Cary, NC.

27. Terayama K (1993). Effects of lead on electrophoretic mobility, membrane sialic acid, deformability and survival of rat erythrocytes. Industrial Health 31: 113-126.

28. Tessier A, Campbell PGC and Bisson M (1999). Sequential extraction procedure for the speciation of particular trace metals. Analytical Chemistry 51: 844851.

29. Tu C, Zheng CR and Chen HM (2002). Effect of applying chemical fertilizers on forms of lead and cadmium in red soil. Chemosphere 41: 133-138.

30. Vengris VE and Mare CJ (1974). Lead poisoning in chickens and the effect of lead on interferon and antibody production. Canadian Journal of Comparative Medicine 38: 328-335.

31. WHO (1995). Guidelines for drinking water quality. In: Health criteria and other supporting information. $2^{\text {nd }}$ edn, World Health Organization Geneva 2: 195-201.

32. Yang J, Mosby DE, Casteel SW and Blancher RW (2001). Lead immobilization using phosphoric acid in a smeltercontaminated urban soil. Environmental Science \& Technology 35: 3553-3559. 